\title{
Effects of soybean silage on feeding behavior, performance, and meat quality of lambs
}

\author{
V.M. Protes ${ }^{\mathrm{a}}$, C. Costa $^{\mathrm{a}}$, C.M. Pariz ${ }^{\mathrm{a}}$, A.M. Castilhos ${ }^{\mathrm{a}}$, P.R.L. Meirelles ${ }^{\mathrm{a}}$, V.Z. Longhini ${ }^{\mathrm{b}}$, R.O. Roça ${ }^{\mathrm{c}}$, \\ H.A. Ricardo ${ }^{\mathrm{d}, *}$, V.F.P. Melo ${ }^{\mathrm{a}}$ \\ ${ }^{a}$ Departamento de Melhoramento e Nutrição Animal, Faculdade de Medicina Veterinária e Zootecnia (FMVZ), Universidade Estadual Paulista (UNESP), 18618-000, \\ Botucatu, SP, Brazil \\ b Departamento de Zootecnia, Faculdade de Ciências Agrárias e Veterinárias (FCAV), Universidade Estadual Paulista (UNESP), 14884-900, Jaboticabal, SP, Brazil \\ ${ }^{\mathrm{c}}$ Departamento de Sociologia, Economia e Tecnologia, Faculdade de Ciências Agronômicas (FCA), Universidade Estadual Paulista (UNESP), 18610-307, Botucatu, SP, \\ Brazil \\ d Departamento de Produção Animal, Faculdade de Medicina Veterinária e Zootecnia (FMVZ), Universidade Estadual Paulista (UNESP), 18618-000, Botucatu, SP, Brazil
}

\section{A R T I C L E I N F O}

\section{Keywords:}

Feeding behavior

Roughage

Shear force

Sheep

Soybean silage

\begin{abstract}
A B S T R A C T
The objective of this study was to evaluate the performance, feeding behavior, carcass traits, and meat quality of feedlot lambs using 2 types of silage, sorghum or soybean. Twenty-eight male non-castrated market lambs weighting $20 \pm 2 \mathrm{~kg}$ were used. Diets were formulated to be isonitrogenous and isocaloric. The animals were slaughtered after 50 days of experiment, with $32.13 \pm 5.09 \mathrm{~kg}$ of body weight. Lambs fed with soybean silage showed increased time for feed intake $(P=0.01)$. There was no difference for allowed daily gain, dry matter intake, feed conversion, and carcass traits between diets. Meat from lambs fed with soybean silage showed decreased shear force $(P=0.001)$ compared to sorghum silage, with no differences $(P>0.05)$ for chemical composition, color, and cooking loss. The intake of sorghum silage increased $(P<0.05)$ C6:0, C16:0, C20:0, C14:1, and C16:1 fatty acids content of Longissimus lumborum intramuscular fat. The intake of soybean silage

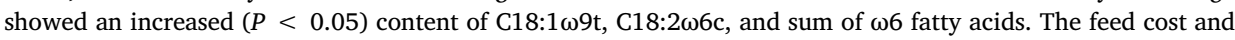
profit from the use of sorghum and soybean silage were US\$ 0.12 and US\$ $0.13 / \mathrm{Lamb} / \mathrm{d}$, US\$ 16.68 and US\$ $16.97 / \mathrm{Lamb}$, respectively. The use of soybean silage provides the same performance and carcass traits of lambs compared with sorghum silage, and it shows the benefit of decrease shear force and the proportion of hypercholesterolemic fatty acids C16:0 and C16:1.
\end{abstract}

\section{Introduction}

Sorghum (Sorghum bicolor, (L.) Moench) is a tropical crop widely used for silage production, with high dry matter (DM) production, low buffering capacity, and high content of water-soluble carbohydrates (Fribourg, 1995; Kempton et al., 1984; McDonald, 1981; Rooney et al., 2007). Campanili et al. (2017) found that the use of sorghum silage does not prejudice the feeding behavior and improves fiber digestibility and grain ruminal degradability. Cattani et al. (2017) highlight, in general, that sorghum silage does not present any impairment in animal performance, however, sorghum silage based diets should be supplemented with grains to compensate for the low starch content. In Brazil, sorghum silage is the third type of roughage most used in ruminant feedlot.

Soybean is commonly used as a grain crop worldwide, with a significant impact in many economies. However, in some countries, such as Canada and US, soybean first use was as forage crop, which shows an increased interest in livestock production systems. Soybean silage can supply the protein requirements of the animals, reduce the feed costs, improve the profitability, and benefit the soil fertility and structure when intercropping with others grains crops (Vargas-Bello-Pérez et al., 2008; Spanghero et al., 2015; Nkosi et al., 2016).

For the production of soybean silage, it is recommended that the crop be harvested between the growth stages R5 and R7. Under these conditions, silage generally presents the best combination of low fiber, high protein content, and digestible energy (Açiköz et al., 2013; Darmosarkoro et al., 2001; Fehr et al., 1971; Hintz and Albrecht, 1994; Lee et al., 2014; Munoz et al., 1983; Sheaffer et al., 2001; Zhai et al., 2008). In this study, the objective was to evaluate the feeding behavior, performance, carcass traits, and meat quality of feedlot lambs fed with soybean silage, compared to sorghum silage.

\footnotetext{
* Corresponding author at: Fazenda Experimental Lageado, Caixa Postal 237, UNESP Campus de Botucatu, Botucatu, SP, Brazil.

E-mail address: helioar@fmvz.unesp.br (H.A. Ricardo).
} 


\section{Material and methods}

\subsection{Animals}

All procedures carried out in the experiment followed the ARRIVE guidelines (Kilkenny et al., 2013) and EU Directive 2010/63/EU for animal experiments (European Union, 2010). The experiment was approved by the Ethics Committee on the Use of Animals (CEUA) of the School of Veterinary Medicine and Animal Science (FMVZ/UNESP), with the protocol $n^{\circ}$ 04/2014-CEUA.

The experiment was conducted at the Lageado Experimental Farm of FMVZ/UNESP, in Botucatu-SP $\left(22^{\circ} 51^{\prime} 01^{\prime \prime S} 48^{\circ} 25^{\prime} 28^{\prime \prime} \mathrm{W}\right.$, and altitude of $777 \mathrm{~m}$ ). In the feedlot, there were 28 individual covered pens of $2.9 \mathrm{~m}^{2}$ with ground floor, with ad libitum access to water and individual feed bunk.

Twenty-eight male market lambs, with mean BW ( \pm SD) of $20 \pm 2 \mathrm{~kg}$ and 60 days of age, were randomly allocated into 2 treatments (sorghum silage or soybean silage), with 14 repetitions. At the beginning of the experiment, the animals received prophylactic management against internal parasites $(3 \mathrm{~mL} / \mathrm{animal}$ of levamisole chloride).

\subsection{Soybean silage and diets}

For the production of soybean silage, the cultivar used was BMX Potência RR (Seeds Lazarotto, Entre Ijuís, Rio Grande do Sul, Brazil), from the semi-mature maturation group (6.6). Seeding was carried out at $3 \mathrm{~cm}$ depth, with a density of 400,000 seeds/ha and a spacing of $0.45 \mathrm{~m}$. The plants were harvested at growth stage R7 (beginning of grain maturation and $50 \%$ yellowish leaves), at $10-15 \mathrm{~cm}$ height, with the material being chopped into $4 \mathrm{~mm}$ average particles. A portion of the harvested material was used in the preparation of the experimental silos for evaluations of the chemical composition of the silages; the remaining material was stored in $200 \mathrm{~L}$ capacity drums.

The experimental diets were isonitrogenous (Table 1) and were formulated based on nutritional requirements of growth for a lamb with $20 \mathrm{~kg}$ of BW (NRC, 2007). The adaptation to diet and facilities was realized during 14 days and the diet was individually offered on 2 schedules (0700 and $1600 \mathrm{~h}$ ), with ad libitum access to water and individual feed bunk. Dry matter, crude protein (CP), and ether extract

Table 1

Ingredients and diets composition.

\begin{tabular}{lll}
\hline & Diet & \\
\cline { 2 - 3 } & Sorghum silage & Soybean silage \\
\hline Ingredients, \% & & \\
Sorghum silage & 24.96 & 0.00 \\
Soybean silage & 0.00 & 35.00 \\
Grounded corn & 63.70 & 26.91 \\
Soybean meal & 8.26 & 0.00 \\
Wheat meal & 0.00 & 34.84 \\
Limestone & 1.27 & 1.44 \\
Mineral premix & 1.28 & 1.28 \\
Ionophore & 0.03 & 0.03 \\
Ammonium chloride & 0.50 & 0.50 \\
Composition & & \\
Dry matter, \% & 62.71 & 54.40 \\
Crude protein, \% DM & 11.89 & 19.33 \\
Metabolizable protein, \% DM & 11.74 & 11.46 \\
Ether extract, \% DM & 3.90 & 7.66 \\
Neutral detergent fiber, \% DM & 22.32 & 32.12 \\
Acid detergent fiber, \% DM & 10.50 & 13.96 \\
Total digestive nutrients, \% DM & 79.90 & 77.50 \\
Metabolizable energy, Mcal/kg DM & 2.88 & 2.80 \\
\hline
\end{tabular}

a Composition: $12.0 \% \mathrm{Ca}, 0 \% \mathrm{P}, 11.0 \% \mathrm{Mg}, 21.0 \% \mathrm{~S}, 0.038 \% \mathrm{Se}, 8.35 \% \mathrm{Zn}$, $2.63 \% \mathrm{Mn}, 0.25 \%$ I, $0.25 \%$ Co.

b Rumensin : $10 \mathrm{~g}$ of Sodic Monensin/100 g.
Table 2

Fatty acid composition of the diets ( $\%$ of total FAME).

\begin{tabular}{|c|c|c|}
\hline & \multicolumn{2}{|l|}{ Diet } \\
\hline & Sorghum silage & Soybean silage \\
\hline C4:0 & 0.21 & 3.16 \\
\hline C6:0 & 0.04 & 0.04 \\
\hline C8:0 & 0.01 & 0.01 \\
\hline C10:0 & 0.004 & 0.01 \\
\hline $\mathrm{C} 11: 0$ & 0.00 & 0.002 \\
\hline C12:0 & 0.02 & 0.09 \\
\hline C14:0 & 0.12 & 0.16 \\
\hline C15:0 & 0.06 & 0.06 \\
\hline C16:0 & 15.37 & 14.93 \\
\hline $\mathrm{C} 17: 0$ & 0.09 & 0.11 \\
\hline C18:0 & 2.15 & 3.04 \\
\hline C20:0 & 0.47 & 0.40 \\
\hline $\mathrm{C} 21: 0$ & 0.009 & 0.01 \\
\hline C22:0 & 0.17 & 0.39 \\
\hline C23:0 & 0.14 & 0.22 \\
\hline $\mathrm{C} 24: 0$ & 0.27 & 0.30 \\
\hline$\Sigma$ SFA & 19.12 & 22.92 \\
\hline $\mathrm{C} 16: 1$ & 0.14 & 0.07 \\
\hline $\mathrm{C} 17: 1$ & 0.03 & 0.03 \\
\hline $\mathrm{C} 18: 1 \omega 7 \mathrm{c}$ & 1.02 & 1.72 \\
\hline $\mathrm{C} 18: 1 \omega 9 \mathrm{c}$ & 30.68 & 19.78 \\
\hline $\mathrm{C} 18: 1 \omega 9 \mathrm{t}$ & 0.22 & 0.16 \\
\hline C20:1 & 0.21 & 0.57 \\
\hline $\mathrm{C} 22: 1 \omega 9$ & 0.005 & 0.003 \\
\hline C24:1 & 0.004 & 0.00 \\
\hline$\Sigma$ MUFA & 32.30 & 22.33 \\
\hline$C 18: 2 \omega 6 c$ & 46.09 & 49.33 \\
\hline $\mathrm{C} 18: 3 \omega 3$ & 1.93 & 4.78 \\
\hline $\mathrm{C} 18: 3 \omega 6$ & 0.008 & 0.003 \\
\hline C20:2 & 0.005 & 0.02 \\
\hline $\mathrm{C} 20: 3 \omega 6$ & 0.06 & 0.00 \\
\hline $\mathrm{C} 20: 4 \omega 6$ & 0.008 & 0.03 \\
\hline $\mathrm{C} 20: 5 \omega 3$ & 0.003 & 0.001 \\
\hline $\mathrm{C} 22: 5 \omega 3$ & 0.001 & 0.00 \\
\hline $\mathrm{C} 22: 6 \omega 3$ & 0.00 & 0.006 \\
\hline$\Sigma$ PUFA & 48.11 & 54.17 \\
\hline$\Sigma \omega 6$ & 48.10 & 54.15 \\
\hline$\Sigma \omega 3$ & 1.94 & 4.79 \\
\hline PUFA:SFA & 2.52 & 2.36 \\
\hline$\omega 6: \omega 3$ & 24.86 & 11.31 \\
\hline $\mathrm{NI}$ & 0.47 & 0.59 \\
\hline
\end{tabular}

$\Sigma$ SFA: sum of saturated fatty acid; $\Sigma$ MUFA: sum of monounsaturated fatty acid; $\Sigma$ PUFA: sum of polyunsaturated fatty acid; $\Sigma \omega 6$ : sum of omega 6 fatty acid; $\Sigma$ $\omega 3$ : sum of omega 3 fatty acid; NI: fatty acids not identified.

(EE) were determined according to AOAC (2007), while NDF and ADF determined according to Van Soest et al. (1991) adapted by Mertens et al. (2002). Total digestible nutrients (TDN) were estimated according to NRC (2007). Metabolizable protein (MP) and energy (ME) of the diets were calculated by Small Ruminant Nutrition System (Tedeschi et al., 2010).

The fatty acids profile from each diet is presented in Table 2, and was performed using the technique described by Rodríguez-Ruiz et al. (1998). Samples were put in test tubes with $1 \mathrm{~mL}$ of the methylation mixture (methanol/acetyl chloride, $20: 1 \mathrm{v} / \mathrm{v}$ ) and $0.5 \mathrm{~mL}$ hexane, and were heated at $100{ }^{\circ} \mathrm{C}$ for $10 \mathrm{~min}$. After the formation of a single methanol/hexane phase, samples were cooled to room temperature, and $1 \mathrm{~mL}$-distilled water was added. The hexanic phase was extracted and placed into the chromatograph vial for injection.

A GC Finnigan Focus model (Varian, Palo Alto, California), which was equipped with a flame (Sigma-Aldrich Corp., St. Louis, MO) ionization detector and a capillary column (CP-Sil 88, Varian) that was $100 \mathrm{~m}$ long with a $0.25 \mu \mathrm{m}$ internal diameter and $0.20 \mu \mathrm{m}$ film thickness was used. Hydrogen was used as the carrier gas at a flow rate of $1.8 \mathrm{~mL} / \mathrm{min}$. The initial oven temperature program was $70^{\circ} \mathrm{C}$, and a wait time of $4 \mathrm{~min}$ was used. The temperature was then raised to $175^{\circ} \mathrm{C}$ (at $13{ }^{\circ} \mathrm{C} / \mathrm{min}$ ), with a wait time of $27 \mathrm{~min}$, followed by another 
temperature increase to $215^{\circ} \mathrm{C}$ (at $40{ }^{\circ} \mathrm{C} / \mathrm{min}$ ), with a standby time of $9 \mathrm{~min}$; finally, the temperature was increased at $7{ }^{\circ} \mathrm{C} / \mathrm{min}$ to $230^{\circ} \mathrm{C}$, at which temperature the sample was maintained for $5 \mathrm{~min}$, for a total time of $65 \mathrm{~min}$. The vaporizer temperature was $250^{\circ} \mathrm{C}$, and the detector temperature was $300^{\circ} \mathrm{C}$.

\subsection{Animal performance and feeding behavior}

The outs and feedstuffs in a feed bunk were weighed daily to achieve a total feed intake of the animal. Feed offered was adjusted every day, in order to have remains equal to $5 \%$ of diet and allow an ad libitum feeding. Allowed daily gain, daily dry matter intake (DMI), DMI as a percentage of $\mathrm{BW}$, and feed conversion (FC) were used to evaluate animal performance.

The animals were observed for 2 periods of $24 \mathrm{~h}$ at 16 day, after diet adaptation, and 26 day of feedlot to evaluate feeding behavior. Direct observation (scan) of the animals was the method used, adapted from Haddad and Obeidat (2007). It consisted of animal observations every $5 \mathrm{~min}$, and the animal behaviors were noted in an ethogram with parameters of intake, rumination, leisure, and other activities.

\subsection{Carcass traits}

The slaughter was carried out in a commercial slaughterhouse after 50 days of experiment, when the mean BW of lambs was $32.13 \pm 5.09 \mathrm{~kg}$. Lambs were held overnight without feed, with free access to water. Hot carcass weight (HCW) was recorded and used to calculate the hot carcass yield $(\mathrm{HCY}=[\mathrm{HCW} / \mathrm{BW}] \times 100)$. After $24 \mathrm{~h}$ of chilling at $4{ }^{\circ} \mathrm{C}$, the cold carcass weight (CCW) was recorded and used to obtain the cold carcass yield $(\mathrm{CCY}=[\mathrm{CCW} / \mathrm{BW}] \times 100)$ and chilling losses (CL). Longissimus muscle area and carcass fat thickness were measured on the Longissimus thoracis muscle between the 12th and 13th ribs.

\subsection{Meat quality}

After the chilling of the carcasses, samples from Longissimus lumborum (LL) were collected from de right side of each carcass, between the first and the last lumbar vertebra, and were vacuum packaged and frozen at $-20^{\circ} \mathrm{C}$ in a domestic freezer until the analysis. One week after slaughter, samples were thawed overnight and slices of $2.5 \mathrm{~cm}$ were taken and used to assess chemical composition, colour, cooking loss, shear force, and composition of fatty acids. The $\mathrm{pH}$ was obtained in intact samples, before sample slicing, of LL with a Hanna $\mathrm{pH}$ meter (Model HI 99163; Hanna Instruments, Woonsocket, RI). The content of moisture, ash, protein and intramuscular fat were obtained according to AOAC (2007) method.

Colour, cooking loss, and shear force were performed according to Honikel (1998), with different samples for each procedure and some adaptations. Thawed samples were removed from the vacuum packages and were allowed to bloom for $30 \mathrm{~min}$. CIE L* (lightness), a* (redness), and $b^{*}$ (yellowness) values were measured on the surface using a Minolta CR-400 colorimeter (Konica Minolta Sensing, Osaka, Japan) with illuminant D65, $8 \mathrm{~mm}$ aperture, and $10^{\circ}$ observer angle.

After removing subcutaneous fat, the samples were cooked in a temperature-controlled water bath to an internal temperature of $75^{\circ} \mathrm{C}$. Internal temperature was measured using a digital thermometer inserted at the geometric center of the sample. The samples were weighed before and after cooking. Cooking loss was calculated from the difference in the weight of raw and cooked samples and was expressed as percentage of initial weight.

After determining cooking loss, the cooked samples were stored for $12 \mathrm{~h}$ at $4{ }^{\circ} \mathrm{C}$. Six cylindrical cores of $1 \mathrm{~cm}$ diameter, in the direction of the muscle fiber, were taken from the samples. These cores were sheared using Warner-Bratzler probe attached to a TA-TX2i texture analyzer (Stable Micro System, Surrey, United Kingdom) set at a speed of $20 \mathrm{~cm} / \mathrm{min}$.

The fatty acid composition of the meat was analyzed by extraction of total lipids from $4.0 \mathrm{~g}$ of wet samples, using chloroform/methanol $(2 / 1 ; \mathrm{v} / \mathrm{v})$ by a period of ten minutes, according to Folch et al. (1957). For all saponification process were used methanol, chloroform, and KCL $0.88 \%$ as chemicals. One microliter of fatty acid methyl esters pipetted from supernatant were quantified by gas-chromatography (SHIMADZU - GC 17A), using a flame ionization detector, "Split/splitless" injector, DB-Wax capillary columm $(60 \mathrm{~m} \times 0.25 \mathrm{~mm}$; J\&W Scientific).

The initial column temperature was held at $80^{\circ} \mathrm{C}$ for $2 \mathrm{~min}$ at a rate of $3{ }^{\circ} \mathrm{C} / \mathrm{min}$ and then raised to $180^{\circ} \mathrm{C}$ at a rate of $30^{\circ} \mathrm{C} / \mathrm{min}$, kept at this temperature for $30 \mathrm{~min}$, and after this time, raised to $200^{\circ} \mathrm{C}$ at a rate of $3{ }^{\circ} \mathrm{C} / \mathrm{min}$, remaining at this temperature for $108 \mathrm{~min}$. The detector temperature $240^{\circ} \mathrm{C}$ with helium carrier gas total flow of $8.0 \mathrm{~mL} / \mathrm{min}$; splitter ratio 1:50. For the identification of fatty acids, their retention times were compared with those of the methyl esters of standards (Sigma-Aldrich Corp.), while the measurement was carried out by area normalization expressing the result as a percentage area of each acid on the total area fatty acids (\%), according to the methodology of Hartman and Lago, (1973).

\subsection{Statistical analysis}

The design was a completely randomized in 2 types of silage (sorghum or soybean). Behavior, animal performance, carcass traits, meat quality, and composition of fatty acids were analyzed by PROC GLM from SAS (SAS Inst. Inc., Cary, NC) by the model:

$\mathrm{Y}_{\mathrm{i}}=\mu+\mathrm{S}_{\mathrm{i}}+\mathrm{e}_{\mathrm{ik}}$

where: where $\mathrm{Y}$ is the behavior, performance, carcass, and meat variables; $\mu$ is the mean value; $S$ is the effect of silage type; e is the residual error. Effects were considered significant at $P$-value $\leq 0.05$.

\section{Results}

Animals fed with sorghum silage spent 11.9, 1.1, 28.9, and $58.1 \%$ of the time in feed intake, water intake, rumination, and leisure, respectively. The soybean silage resulted in $15.8,1.0,28.0$, and $55.3 \%$ of the time for feed intake, water intake, rumination, and leisure, respectively. For the average time (min/day) of feeding behavior traits, lambs fed with soybean silage spent longer time in feed intake $(P=0.01)$ than animals fed with sorghum silage (227.5 vs. $171.54 \mathrm{~min} /$ day; Table 3 ).

There was no effect of silage type $(P>0.05)$ on animal performance (Table 3 ) and carcass traits (Table 4). For quality traits of LL (Table 5), animals fed with soybean silage showed decreased shear force $(P<0.01)$ compared to those fed with sorghum silage (5.91 vs. $6.84 \mathrm{~kg})$.

The fatty acid composition of LL intramuscular fat according to silage type is shown in Table 6 . The sorghum silage increased the proportion of C6:0, C16:0, C20:0, C14:1, and C16:1 $(P<0.05)$. Lambs fed

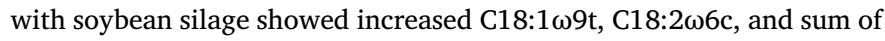

Table 3

Effects of silage type on lamb performance and feeding behavior.

\begin{tabular}{|c|c|c|c|c|}
\hline & Sorghum silage & Soybean silage & $\mathrm{SEM}^{\mathrm{a}}$ & $P$-value \\
\hline Average daily gain, $g /$ day & 232 & 244 & 0.20 & 0.56 \\
\hline Dry matter intake, g/day & 866 & 939 & 0.60 & 0.26 \\
\hline Dry matter intake, $\%$ BW & 3.41 & 3.63 & 0.002 & 0.17 \\
\hline Feed conversion ${ }^{\mathrm{b}}$ & 3.80 & 3.90 & 1.90 & 0.59 \\
\hline Feed intake, min/day & 171.54 & 227.50 & 10.27 & 0.01 \\
\hline Water intake, min/day & 15.38 & 14.17 & 3.35 & 0.85 \\
\hline Rumination, min/day & 415.38 & 402.50 & 15.24 & 0.67 \\
\hline Leisure, min/day & 834.62 & 795.83 & 16.96 & 0.25 \\
\hline
\end{tabular}

a SEM: Standard error of the mean.

b Kilograms of diet intake per $\mathrm{kg}$ of body weight gain. 
Table 4

Effects of silage type on lamb carcass traits.

\begin{tabular}{|c|c|c|c|c|}
\hline & $\begin{array}{l}\text { Sorghum } \\
\text { silage }\end{array}$ & $\begin{array}{l}\text { Soybean } \\
\text { silage }\end{array}$ & SEM $^{\mathrm{a}}$ & $P$-value \\
\hline Hot carcass weight, kg & 14.56 & 14.62 & 0.71 & 0.93 \\
\hline Hot carcass yield, \% & 45.82 & 45.02 & 0.84 & 0.35 \\
\hline Cold carcass weight, $\mathrm{kg}$ & 14.30 & 14.34 & 0.69 & 0.95 \\
\hline Cold carcass yield, $\%$ & 45.01 & 44.15 & 0.78 & 0.29 \\
\hline Chilling losses, \% & 1.76 & 1.91 & 0.21 & 0.49 \\
\hline Longissimus muscle area, $\mathrm{cm}^{2}$ & 14.32 & 13.77 & 2.31 & 0.50 \\
\hline $\begin{array}{l}\text { Subcutaneous fat thickness, } \\
\text { mm }\end{array}$ & 1.31 & 1.34 & 0.17 & 0.89 \\
\hline
\end{tabular}

a SEM: Standard error of the mean.

Table 5

Effects of silage type on quality traits of lamb Longissimus muscle.

\begin{tabular}{lllll}
\hline & Sorghum silage & Soybean silage & SEM $^{\mathrm{a}}$ & $P$-value \\
\hline Moisture, \% & 74.80 & 74.85 & 0.34 & 0.92 \\
Ash, \% & 1.18 & 1.20 & 0.01 & 0.20 \\
Crude protein, \% & 20.24 & 21.02 & 0.35 & 0.14 \\
Ether extract, \% & 2.76 & 2.62 & 0.36 & 0.78 \\
pH & 5.77 & 5.77 & 0.02 & 0.98 \\
Lightness, L* & 38.38 & 39.42 & 0.71 & 0.31 \\
Redness, a* & 17.92 & 18.10 & 0.47 & 0.79 \\
Yellowness, b* & 4.88 & 5.16 & 0.35 & 0.58 \\
Cooking loss, \% & 26.58 & 26.80 & 1.22 & 0.90 \\
Shear force, kg & 6.84 & 5.91 & 0.17 & 0.001 \\
\hline
\end{tabular}

a SEM: Standard error of the mean.

Table 6

Effects of silage type on fatty acid composition of lamb Longissimus muscle (\% of total FAME).

\begin{tabular}{|c|c|c|c|c|}
\hline & Sorghum silage & Soybean silage & SEM & $P$-value \\
\hline C6:0 & 0.08 & 0.05 & 0.01 & 0.03 \\
\hline C8:0 & 0.28 & 0.25 & 0.01 & 0.20 \\
\hline C13:0 & 0.23 & 0.19 & 0.18 & 0.26 \\
\hline $\mathrm{C} 14: 0$ & 3.19 & 2.93 & 0.15 & 0.24 \\
\hline $\mathrm{C} 16: 0$ & 29.33 & 27.51 & 0.53 & 0.02 \\
\hline $\mathrm{C} 17: 0$ & 1.04 & 0.69 & 0.15 & 0.12 \\
\hline C18:0 & 18.70 & 20.30 & 1.84 & 0.54 \\
\hline C20:0 & 0.34 & 0.26 & 0.01 & 0.01 \\
\hline$\sum$ SFA & 53.23 & 52.43 & 1.90 & 0.77 \\
\hline C14:1 & 0.01 & 0.00 & 0.00 & 0.01 \\
\hline $\mathrm{C} 16: 1$ & 2.36 & 1.98 & 0.10 & 0.01 \\
\hline $\mathrm{C} 18: 1 \omega 9 \mathrm{c}$ & 33.09 & 32.50 & 1.66 & 0.80 \\
\hline $\mathrm{C} 18: 1 \omega 9 \mathrm{t}$ & 0.10 & 0.27 & 0.05 & 0.04 \\
\hline C20:1 & 0.61 & 0.59 & 0.03 & 0.69 \\
\hline $\mathrm{C} 22: 1 \omega 9$ & 0.66 & 0.41 & 0.22 & 0.45 \\
\hline$\Sigma$ MUFA & 36.72 & 35.87 & 1.63 & 0.71 \\
\hline$C 18: 2 \omega 6 c$ & 4.07 & 5.42 & 0.26 & 0.01 \\
\hline $\mathrm{C} 18: 3 \omega 3$ & 0.30 & 0.38 & 0.11 & 0.63 \\
\hline $\mathrm{C} 20: 3 \omega 6$ & 1.64 & 1.42 & 0.12 & 0.21 \\
\hline $\mathrm{C} 20: 4 \omega 6$ & 1.25 & 1.26 & 0.15 & 0.96 \\
\hline $\mathrm{C} 20: 5 \omega 3$ & 1.04 & 0.87 & 0.12 & 0.35 \\
\hline $\mathrm{C} 22: 6 \omega 3$ & 0.62 & 0.19 & 0.44 & 0.52 \\
\hline$\Sigma$ PUFA & 8.88 & 9.78 & 0.45 & 0.18 \\
\hline$\Sigma \omega 6$ & 7.08 & 8.23 & 0.38 & 0.04 \\
\hline$\sum \omega 3$ & 1.68 & 1.43 & 0.18 & 0.31 \\
\hline PUFA:SFA & 0.16 & 0.19 & 0.01 & 0.22 \\
\hline$\omega 6: \omega 3$ & 4.87 & 6.47 & 0.65 & 0.10 \\
\hline AI & 0.93 & 0.88 & 0.04 & 0.55 \\
\hline NI & 1.16 & 1.90 & 0.39 & 0.19 \\
\hline
\end{tabular}

SEM: standard error of mean; $\Sigma$ SFA: sum of saturated fatty acid; $\Sigma$ MUFA: sum of monounsaturated fatty acid; $\Sigma$ PUFA: sum of polyunsaturated fatty acid; $\Sigma$ $\omega 6$ : Sum of omega 6 fatty acid; $\Sigma \omega 3$ : sum of omega 3 fatty acid; AI: Atherogenic index $\left(\mathrm{AI}=(\mathrm{C} 12: 0+4 \times \mathrm{C} 14: 0+\mathrm{C} 16: 0) /\left(\Sigma\right.\right.$ MUFA $\left.\left.+\sum \omega 3+\Sigma \omega 6\right)\right)$; NI: fatty acids not identified.
Table 7

Costs and profits from the use of soybean silage compared to sorghum silage.

\begin{tabular}{lll}
\hline & Sorghum silage & Soybean silage \\
\hline Feed cost, US\$/Lamb/day & 0.12 & 0.13 \\
Cost of the gain, US\$/kg & 0.56 & 0.55 \\
Carcass value, US\$/Lamb & 59.92 & 60.35 \\
Profit, US\$/Lamb & 16.68 & 16.97 \\
\hline
\end{tabular}

$\omega 6$ fatty acids compared with sorghum silage $(P<0.05)$. The feed cost with sorghum and soybean silage was 0.12 and 0.13 (US\$/Lamb/d) respectively. Other costs and profits from the use of the two types of silage is show in Table 7.

\section{Discussion}

The feed intake of ruminants is controlled by the central nervous system in response to feedback of physical, chemical, and physiological factors (Fisher, 2002; Provenza, 1995). Even with increased NDF content of soybean silage compared to sorghum (32.12 vs. $22.32 \%)$ that could affect the intake (Allen, 2000), DMI was the same for the two silages (Table 3). The increased content of EE from soybean silage (Table 1) also could affect DMI. High levels of dietary lipids can cause fermentation disorders, decrease feed intake and performance of ruminants (Erickson and Barton, 1987; Jordan et al., 2006; Van Soest, 1994). However, Camilo et al. (2015) assessed diets with an average EE content of $8.46 \%$ of DM and did not find differences for DMI, as the same way that the present study.

Coffey et al. (1995) assessed the preference by sheep for silages from corn and soybean, the last one at R2, R4, or R6 growth stages. The corn silage was preferred rather than soybean. However, within the soybean silages, R6 silage some-what compromises digestibility of the forage but provides a silage of higher acceptance by sheep. The soybean silage of the present study was produced at R7 growth stage, and it could contribute to the longer time spent for feed intake. Cardoso et al. (2006) showed that the dietary level of NDF less than $44 \%$ has no influence on the time spent for intake of feedlot lambs. As there wasńt any factor that altered the DMI, it is suggested that there was a fractionation of feed intake along the day influenced by the lower acceptance of the soybean silage.

There is little information relating shear force values and consumer preferences for tenderness in lamb and appropriate threshold levels. Factors such as region of production, season, and aging period affect the results of shear force. Considering these factors and the available literature, the shear force value considered as a threshold to rate the tenderness of lamb meat between acceptable or unacceptable is $5 \mathrm{~kg}$ (Safari et al., 2002). The meat from lambs fed with soybean silage showed a value near to this suggested and lower compared to sorghum silage. No carcass and quality trait could explain this difference, as carcass fat thickness, meat intramuscular fat, $\mathrm{pH}$, or cooking losses. Garmyn et al. (2011) found a significant negative correlation between shear force and C18:1 $\omega 9 \mathrm{t}$ content for beef. Soybean silage provided increased content of C18:1 $\omega 9 \mathrm{t}$ compared to sorghum, and it could help to explain the shear force differences. However, although significant, the authors highlights that this relationship is weak.

Hintz et al. (1992) reported that CP concentrations of soybean silage increased from R5 to R7, and whole-plant fiber concentrations decreased from R5 to R7. Machado et al. (2013) found that soybean silage showed $9.5 \%$ more soluble fraction of $\mathrm{CP}$, and degradation rate of $\mathrm{B}$ fraction 2.5 times higher than sorghum silage. Spanghero et al. (2015) found that soybean silage at R6 vegetative stage shows increased CP digestibility compared to silage harvested at R4 and R5. These findings suggest that there was an additive effect of soybean silage, on the total diet, on the availability of AA for muscle deposition. Associated with these nutritional factors, the fractionation of the diet with soybean 
silage, with more time spent for intake (Table 3), also could have improved the production of microbial protein, and consequently the $\mathrm{CP}$ digestibility and AA availability.

Early works, with beef and pork, for example, showed that tenderness is positively related to the cross-sectional areas of the muscle fibres (Dikeman et al., 1986; Maltin et al., 1997; Seideman and Crouse, 1986). The decreased shear force of samples from lambs fed with soybean silage, compared to sorghum, can be related with increased digestibility of $\mathrm{CP}$ and AA availability that can promote the fiber development, with a consequent increase in their diameters.

Diet composition is the major factor influencing the fatty acid profile of meat from ruminants because the absorbed fatty acids are of dietary origin as well as the result of rumen biohydrogenation of dietary lipids (Buccioni et al., 2012). Soybean oil is made up of five fatty acids, with averages $12 \%$ of $\mathrm{C} 16: 0 ; 4 \%$ of $\mathrm{C} 18: 0 ; 23 \%$ of $\mathrm{C} 18: 1 ; 53 \%$ of $\mathrm{C} 18: 2$; 8\% of C18:3 (Oliva et al., 2006; Lee et al., 2007). According to Sinclair (2007), the supply of oilseeds at sheep finishing diets can decrease the concentration of C16: 0 and increase of C18:2 $\omega 6$ in the tissues, which occurred with the animals fed with soybean silage.

The linoleic acid decreases the serum concentration of LDL-cholesterol, but may increase the risk of coronary heart disease when it replaces the major dietary SFA (Bazinet and Chu, 2014). In general, the concentration of $\omega 6$ fatty acids in lamb meat contributes $0.5-1.0 \%$ of the recommended energy intake for humans. When consumed with other foods, this contribution falls to the safe levels recommended by the World Health Organization and Uauy (2008) (Chikwanha et al., 2017).

Despite the increased concentration of $\omega 6$ fatty acids, the meat of lambs that consumed soybean silage showed a decreased concentration of C16:0 e C16:1. As well as the other SFA, palmitic acid, predominant SFA in soybean oil (Lee et al., 2007), can increase total and LDL-cholesterol concentrations and increase coagulation, inflammation, and insulin resistance in humans (Calder, 2015; Howes et al., 2015). Even belonging to the MUFA group, palmitoleic acid can act as SFA in cholesterol metabolism, increasing LDL and decreasing HDL-cholesterol concentrations (De Fabiani, 2011).

\section{Conclusions}

In conclusion, the use of soybean silage provides the same animal performance, carcass traits and economic benefit compared with sorghum silage diet, while soybean silage diet shows a beneficial decrease of shear force and the proportion of hypercholesterolemic fatty acids $\mathrm{C} 16: 0$ and C16:1.

\section{Conflict of interest}

The author declare no conflict of interest.

\section{Acknowledgements}

The authors thank the São Paulo Research Foundation (FAPESP) (\#grant 2014/00772-6), Brazil. The authors also thank the Coordination of Improvement of Higher Education Personnel (CAPES) for the grant to the first author.

\section{References}

Açiköz, E., Sincik, M., Wietgrefe, G., Sürmen, M., Cecen, S., Yavuz, T., Erdurmus, C., Göksoy, A.T., 2013. Dry matter accumulation and forage quality characteristics of different soybean genotypes. Turkish J. Agric. For. 37, 22-32.

AOAC, 2007. Official Methods of Analysis of AOAC International, Association of Official Analysis Chemists International.

Allen, M.S., 2000. Effects of diet on short-term regulation of feed intake by lactating dairy cattle. J. Dairy Sci. 83, 1598-1624.

Bazinet, R.P., Chu, M.W.A., 2014. Omega-6 polyunsaturated fatty acids: is a broad cholesterol-lowering health claim appropriate? Can. Med. Assoc. J. 186 (43), LP-439.

Buccioni, A., Decandia, M., Minieri, S., Molle, G., Cabiddu, A., 2012. Lipid metabolism in the rumen: new insights on lipolysis and biohydrogenation with an emphasis on the role of endogenous plant factors. Anim. Feed Sci. Technol. 174, 1-25. http://dx.doi. org/10.1016/j.anifeedsci.2012.02.009.

Calder, P.C., 2015. Functional roles of fatty acids and their effects on human health. J. Parenter. Enter. Nutr 39, 18S-32S. http://dx.doi.org/10.1177/0148607115595980.

Camilo, F.R., Vargas Junior, F.M., Ricardo, H.A., Fernandes, A.R.M., Seno, L.O., Osório, J.C.S., Souza, M.R., Mobiglia, A.M., 2015. The intake of thermally processed soybean reduces the feedlot period of lambs independently of roughage to concentrate ratio. J. Anim. Sci. 93, 3084-3090. http://dx.doi.org/10.2527/jas2014-8560.

Campanili, P.R.B., Sarturi, J.O., Ballou, M.A., Trojan, S.J., Sugg, J.D., Ovinge, L.A., Alrumaih, A.U., Pellarin, L.A., Hoffman, A.A., 2017. Effects of silage type and inclusion level on ruminal characteristics and feeding behavior of steers fed finishing diets1. J. Anim. Sci. 95, 4623-4637.

Cardoso, A.R., Carvalho, S., Galvani, D.B., Pires, C.C., Gasperin, B.G., 2006. Ingestive behavior of lambs fed with a diet of different levels of fiber in neutrol detergent. Ciênc. Rural 36, 604-609.

Cattani, M., Guzzo, N., Mantovani, R., Bailoni, L., 2017. Effects of total replacement of corn silage with sorghum silage on milk yield, composition, and quality. J. Anim. Sci. Biotechnol. 8. http://dx.doi.org/10.1186/s40104-017-0146-8.

Chikwanha, O.C., Vahmani, P., Muchenje, V., Dugan, M.E.R., Mapiye, C., 2017. Nutritional enhancement of sheep meat fatty acid profile for human health and wellbeing. Food Res. Int. 0-1. http://dx.doi.org/10.1016/j.foodres.2017.05.005.

Coffey, K.P., Granade, G., V Moyer, J.L., Anderson, D.C., Bush, L.J., 1995. In vitro digestibility and preference by sheep for silages made from whole-plant soybeans1. Prof. Anim. Sci. 11, 81-87. http://dx.doi.org/10.15232/S1080-7446(15)32560-2.

Darmosarkoro, W., Harbur, M.M., Buxton, D.R., Moore, K.J., Devine, T.E., Anderson, I.C., 2001. Growth, development, and yield of soybean lines developed for forage. Agron. J. 93, 1028-1034.

De Fabiani, E., 2011. The true story of palmitoleic acid: between myth and reality. Eur. J. Lipid Sci. Technol. 113, 809-811. http://dx.doi.org/10.1002/ejlt.201100187.

Dikeman, M.E., Reddy, G.B., Arthaud, V.H., Tuma, H.J., Mandigo, R.W., Axe, J.B., 1986. Longissimus muscle quality, palatability and connective tissue histological characteristics of bulls and steers fed different energy levels and slaughtered at four ages the online version of this article, along with updated information and services, is. J. Anim. Sci. 92-101. http://dx.doi.org/10.2527/jas1986.63192x.

Erickson, P.S., Barton, B.A., 1987. Whole soybeans for market lambs. J. Anim. Sci. 64, 1249-1254. http://dx.doi.org/10.2527/jas1987.6441249x.

European Union, 2010. Directive 2010/63/EU of the European Parliament and of the Council of 22 September 2010 on the protection of animals used for scientific purposes. Off. J. Eur. Union. 33-79 (32010L0063).

Fehr, W.R., Caviness, C.E., Burmood, D.T., Pennington, J.S., 1971. Stage of development descriptions for soybeans, Glycine Max (L.) Merrill 1. Crop Sci. 11, 929-931.

Fisher, D.S., 2002. A review of a few key factors regulating voluntary feed intake in ruminants. Crop Sci. 42, 1651-1655. http://dx.doi.org/10.2135/cropsci2002.1651.

Folch, J., Lees, M., Stanley, G.H.S., 1957. A simple method for the isolation and purification of total lipids from animal tissues. J. Biol. Chem. 226, 497-509. http://dx. doi.org/10.1007/s10858-011-9570-9.

Fribourg, H.A., 1995. Summer annual grasses. Introd. Grassland Agric. 463-472.

Garmyn, A.J., Hilton, G.G., Mateescu, R.G., Morgan, J.B., Reecy, J.M., Tait, J.G., Beitz, D.C., Duan, Q., Schoonmaker, J.P., Mayes, M.S., Drewnoski, M.E., Liu, Q., Vanoverbeke, D.L., 2011. Estimation of relationships between mineral concentration and fatty acid composition of longissimus muscle and beef palatability traits. J. Anim. Sci. 89, 2849-2858. http://dx.doi.org/10.2527/jas.2010-3497.

Haddad, S.G., Obeidat, B.S., 2007. Production efficiency and feeding behavior of Awassi lambs and Baladi kids fed on a high concentrate diet. Small Rumin. Res. 69, 23-27. http://dx.doi.org/10.1016/j.smallrumres.2005.12.004.

Hartman, L., Lago, R.C.A., 1973. Rapid preparation of fatty acid methyl esters from lipids. Lab. Pr. 22 (475-476), 494

Hintz, R.W., Albrecht, K.A., 1994. Dry matter partitioning and forage nutritive value of soybean plant components. Agron. J. 86, 59-62.

Hintz, R.W., Albrecht, K.A., Oplinger, E.S., 1992. Yield and quality of soybean forage as affected by cultivar and management practices. Agron. J. 84, 795-798.

Honikel, K.O., 1998. Reference methods for the assessment of physical characteristics of meat. Meat Sci. 49, 447-457. http://dx.doi.org/10.1016/S0309-1740(98)00034-5.

Howes, N.L., Bekhit, A.E.D.A., Burritt, D.J., Campbell, A.W., 2015. Opportunities and implications of pasture-based lamb fattening to enhance the long-chain fatty acid composition in meat. Compr. Rev. Food Sci. Food Saf. 14, 22-36. http://dx.doi.org/ 10.1111/1541-4337.12118.

Jordan, E., Kenny, D., Hawkins, M., Malone, R., Lovett, D.K., O'Mara, F.P., 2006. Effect of refined soy oil or whole soybeans on intake, methane output, and performance of young bulls. J. Anim. Sci. 84, 2418-2425. http://dx.doi.org/10.2527/jas.2005-354.

Kempton, T.J., Kaiser, A.G., Trigg, T.E., 1984. Silage in the 80's. Australian Agricultural Technology.

Kilkenny, C., Browne, W.J., Cuthill, I.C., Emerson, M., Altman, D.G., 2013. Improving bioscience research reporting: the arrive guidelines for reporting animal research. Animals 4, 35-44. http://dx.doi.org/10.3390/ani4010035.

Lee, J.-D., Bilyeu, K.D., Shannon, J.G., 2007. Genetics and breeding for modified fatty acid profile in soybean seed oil. J. Crop Sci. Biotechnol. 10, 201-210.

Lee, E.J., Choi, H.-J., Shin, D.-H., Kwon, C.-H., Shannon, J.G., Lee, J.-D., 2014. Evaluation of forage yield and quality in wild soybeans (Glycine soja Sieb. and Zucc.). Plant Breed. Biotechnol. 2, 71-79.

Machado, P.A.S., Valadares Filho, S.C., Detmann, E., Santos, S.A., Valadares, R.F.D., Ducatti, C., Rotta, P.P., Costa e Silva, L.F., 2013. Development of equations to estimate microbial contamination in ruminal incubation residues of forage produced under tropical conditions using $15 \mathrm{~N}$ as a label1. J. Anim. Sci. 91, 3836-3846. http:// dx.doi.org/10.2527/jas.2012-5636. 
Maltin, C.A., Warkup, C.C., Matthews, K.R., Grant, C.M., Porter, A.D., Delday, M.I., 1997. Pig muscle fibre characteristics as a source of variation in eating quality. Meat Sci. 47, 237-248. http://dx.doi.org/10.1016/S0309-1740(97)00055-7.

McDonald, P., 1981. The Biochemistry of Silage. John Wiley \& Sons, Ltd., Chichester.

Mertens, D.R., Allen, M., Carmany, J., Clegg, J., Davidowicz, A., Drouches, M., Frank, K., Gambin, D., Garkie, M., Gildemeister, B., Jeffress, D., Jeon, C.S., Jones, D., Kaplan, D., Kim, G.N., Kobata, S., Main, D., Moua, X., Paul, B., Robertson, J., Taysom, D., Thiex, N., Williams, J., Wolf, M., 2002. Gravimetric determination of amylase-treated neutral detergent fiber in feeds with refluxing in beakers or crucibles: collaborative study. J. AOAC Int. 85, 1217-1240.

Munoz, A.E., Holt, E.C., Weaver, R.W., 1983. Yield and quality of soybean hay as influenced by stage of growth and plant density 1. Agron. J. 75, 147-149.

NRC, 2007. Nutrient Requirements of Small Ruminants: Sheep, Goats, Cervids, and New World Camelids. The National Academies Press, Washington, DC. http://dx.doi.org/ 10.17226/11654.

Nkosi, B.D., Meeske, R., Langa, T., Motiang, M.D., Modiba, S., Mkhize, N.R., Groenewald, I.B., 2016. Effects of ensiling forage soybean (Glycine max (L.) Merr.) with or without bacterial inoculants on the fermentation characteristics, aerobic stability and nutrient digestion of the silage by Damara rams. Small Rumin. Res. 134, 90-96. http://dx.doi. org/10.1016/j.smallrumres.2015.12.001.

Oliva, M.L., Shannon, J.G., Sleper, D.A., Ellersieck, M.R., Cardinal, A.J., Paris, R.L., Lee, J.D., 2006. Stability of fatty acid profile in soybean genotypes with modified seed oil composition. Crop Sci. 46, 2069-2075. http://dx.doi.org/10.2135/cropsci2005.12. 0474.

Provenza, F.D., 1995. Postingestive feedback as an elementary determinant of food preference and intake in ruminants. J. Range Manag. 48, 2. http://dx.doi.org/10.2307/ 4002498.

Rodríguez-Ruiz, J., Belarbi, E.H., Sánchez, J.L.G., Alonso, D.L., 1998. Rapid simultaneous lipid extraction and transesterification for fatty acid analyses. Biotechnol. Technol. 12, 689-691. http://dx.doi.org/10.1023/A:1008812904017.

Rooney, W.L., Blumenthal, J., Bean, B., Mullet, J.E., 2007. Designing sorghum as a dedicated bioenergy feedstock. Biofuels Bioprod. Biorefin. 1, 147-157. http://dx.doi. org/10.1002/bbb.15.
Safari, E., Channon, H.A., Hopkins, D.L., Hall, D.G., Van de Ven, R., 2002. A national audit of retail lamb loin quality in Australia. Meat Sci. 61, 267-273. http://dx.doi. org/10.1016/S0309-1740(01)00192-9.

Seideman, S.C., Crouse, J.D., 1986. The effects of sex condition, genotype and diet on bovine muscle fiber characteristics. Meat Sci. 17, 55-72. http://dx.doi.org/10.1016/ 0309-1740(86)90083-5.

Sheaffer, C.C., Orf, J.H., Devine, T.E., Jewett, J.G., 2001. Yield and quality of forage soybean. Agron. J. 93, 99-106. http://dx.doi.org/10.2134/agronj2001.93199x.

Sinclair, L.A., 2007. Paper presented at the 9th annual Langford Food Industry Conference, Bristol, 24-25 May 2006 - Nutritional manipulation of the fatty acid composition of sheep meat: a review. J. Agric. Sci. 145, 419-434. http://dx.doi.org/ 10.1017/S0021859607007186.

Spanghero, M., Zanfi, C., Signor, M., Davanzo, D., Volpe, V., Venerus, S., 2015. Effects of plant vegetative stage and field drying time on chemical composition and in vitro ruminal degradation of forage soybean silage. Anim. Feed Sci. Technol. 200, 102-106. http://dx.doi.org/10.1016/j.anifeedsci.2014.11.006.

Tedeschi, L.O., Cannas, A., Fox, D.G., 2010. A nutrition mathematical model to account for dietary supply and requirements of energy and other nutrients for domesticated small ruminants: the development and evaluation of the Small Ruminant Nutrition System. Small Rumin. Res. 89, 174-184.

Van Soest, P.J., Robertson, J.B., Lewis, B.A., 1991. Methods for dietary fiber, neutral detergent fiber, and nonstarch polysaccharides in relation to animal nutrition. J. Dairy Sci. 74, 3583-3597. http://dx.doi.org/10.3168/jds.S0022-0302(91)78551-2.

Van Soest, P.J., 1994. Nutritional Ecology of the Ruminant, A Comstock Bk. Comstock Pub.

Vargas-Bello-Pérez, E., Mustafa a, a F., Seguin, P., 2008. Effects of feeding forage soybean silage on milk production, nutrient digestion, and ruminal fermentation of lactating dairy cows. J. Dairy Sci. 91, 229-235. http://dx.doi.org/10.3168/jds.2007-0484.

World Health Organization, Uauy, REA, 2008. Fats and Fatty Acids in Human Nutrition, Report of an Expert Consultation. FAO, Food and Nutrition Paper (978-92-5106733-8).

Zhai, G., Shen, Y., Zhai, Y., Liu, X., Jiang, H., 2008. Forage yield performance and nutritive value of selected wild soybean ecotypes. Can. J. Plant Sci. 88, 465-472. 